\title{
Metabolism of Methanol by Rhodopseudomonas acidophila
}

\author{
By H. SAHM*, R. B. COX AND J. R. QUAYLE \\ Department of Microbiology, The University, Sheffield SIO $2 T N$
}

(Received I8 September 1975)

\begin{abstract}
SUMMARY
Rhodopseudomonas acidophila strain 10050, grown anaerobically in the light on methanol, contained a methanol and formaldehyde dehydrogenase which could be coupled to phenazine methosulphate; an NAD-linked formaldehyde dehydrogenase which required GSH for activity; and an NAD-linked formate dehydrogenase. The specific activities of these enzymes varied in a non-coordinate manner when the organism was grown on different alcohols, formate or succinate. The affinity of the phenazine methosulphate linked methanol dehydrogenase for methanol was increased Io-fold if the cell-free extract was prepared and assayed in the absence of oxygen. Pulse-labelling experiments with $\left[{ }^{14} \mathrm{C}\right] \mathrm{methanol}$ and $\left[{ }^{14} \mathrm{C}\right]$ bicarbonate indicated that fixation of carbon dioxide occurred via the ribulose diphosphate cycle and $\mathrm{C}_{3}+\mathrm{CO}_{2}$ fixation reaction(s). No evidence was obtained for operation of a reduced $\mathrm{C}_{1}$ fixation sequence. This conclusion was borne out by the enzyme content of cell-free extracts of the organism.
\end{abstract}

\section{INTRODUCTION}

Quayle \& Pfennig (1975) have shown that Rhodopseudomonas acidophila strain I0050 assimilates methanol anaerobically in the light by a process which approximates to:

$$
2 \mathrm{CH}_{3} \mathrm{OH}+\mathrm{CO}_{2} \longrightarrow 3[\mathrm{HCHO}]+\mathrm{H}_{2} \mathrm{O}
$$

where $[\mathrm{HCHO}]$ represents reduced cellular carbon. In this overall process, carbon dioxide functions as an electron sink for the excess electrons in methanol, the reduction of carbon dioxide being effected via the ribulose diphosphate cycle. If all the methanol were oxidized to carbon dioxide before assimilation, the organism would, in effect, be growing autotrophically on methanol, in a similar fashion to Pseudomonas oxalaticus (Quayle \& Keech, 1959) and Rhodopseudomonas palustris (Yoch \& Lindstrom, 1967; Stokes \& Hoare, 1969) growing on formate. There is however the possibility that formaldehyde produced by dehydrogenation of methanol is assimilated as such by a reduced $\mathrm{C}_{\mathbf{1}}$ fixation sequence. If this were so, two net $C_{1}$ assimilation sequences would be operating in the same organism, one at the level of formaldehyde and the other at the level of carbon dioxide.

The work reported in this paper examines these possibilities for the metabolism of methanol by $R h$. acidophila strain 10050.

\section{METHODS}

Growth of the organism in batch culture. The organism was grown at $30^{\circ} \mathrm{C}, \mathrm{pH} 7 \cdot 0$, in basal medium (Quayle \& Pfennig, 1975) except that the trace-element solution SL6 and iron citrate were replaced by chelated trace-element solution $\mathrm{SL}_{4}$ (I ml/l). Solution $\mathrm{SL}_{4}$

* Present address: Gesellschaft für Molekularbiologische Forschung, D-33 Braunschweig-Stockheim, Mascheroder Weg I, West Germany. 
contained $5 \mathrm{~g}$ EDTA (tetra sodium salt) per 1 , adjusted to $\mathrm{pH}_{3} \cdot 8$, to which was added: $\mathrm{FeSO}_{4} \cdot 7 \mathrm{H}_{2} \mathrm{O}, 2 \mathrm{~g} ; \mathrm{ZnSO}_{4} \cdot 7 \mathrm{H}_{2} \mathrm{O}, 0 . \mathrm{I} \mathrm{g} ; \mathrm{MnCl}_{2} .4 \mathrm{H}_{2} \mathrm{O}, 0.03 \mathrm{~g} ; \mathrm{H}_{3} \mathrm{BO}_{3}, 0.3 \mathrm{~g} ; \mathrm{CoCl}_{2} .6 \mathrm{H}_{2} \mathrm{O}$, $0.2 \mathrm{~g} ; \mathrm{CuSO}_{4} .5 \mathrm{H}_{2} \mathrm{O}, 0.01 \mathrm{~g} ; \mathrm{NiCl}_{2} .6 \mathrm{H}_{2} \mathrm{O}, 0.02 \mathrm{~g} ; \mathrm{Na}_{2} \mathrm{MoO}_{4} .2 \mathrm{H}_{2} \mathrm{O}, 0.03 \mathrm{~g}$. Yeast extract was omitted from experiments in which the activity of biosynthetic enzymes was being measured. Organic carbon sources were added to a final concentration of $0.2 \%(w / v)$ unless otherwise stated. The organism was grown in flat-sided bottles (normally $500 \mathrm{ml}$ ), filled to the top, placed $30 \mathrm{~cm}$ from a $60 \mathrm{~W}$ tungsten bulb. It was harvested by centrifuging at $8000 \mathrm{~g}$ for $10 \mathrm{~min}$ and washed with $50 \mathrm{~mm}$-sodium potassium phosphate buffer $\mathrm{pH} 77^{\circ}$.

Growth of the organism in turbidostat culture. For measurement of the specific activity of ribulose diphosphate carboxylase (EC. 4.I.I.39), the organism was grown anaerobically at $30^{\circ} \mathrm{C}$ in a turbidostat (culture vol. I l) similar to that described by Slater \& Morris (1973). The above medium was used, except that methanol was added to a final concentration of $50 \mathrm{~mm}$ (yeast extract absent). The culture vessel was illuminated with tungsten lamps of 4800 lux intensity at the culture surface. The pH was automatically regulated at $7 \cdot 0$ by adding $0.1 \mathrm{M}-\mathrm{H}_{2} \mathrm{SO}_{4}$. The culture was grown at a mean generation time of $29 \mathrm{~h}$ and harvested at a cell density of $380 \mu \mathrm{g}$ dry $\mathrm{wt} / \mathrm{ml}$.

Preparation of cell-free extracts. A suspension of $\mathrm{I} g$ wet $\mathrm{wt}$ of freshly harvested organism in $5 \mathrm{ml}$ of $50 \mathrm{~mm}$-sodium potassium phosphate buffer $(\mathrm{pH} 7 \cdot 0)$ was disrupted in an ultrasonic disintegrator (MSE model $60 \mathrm{~W}$ ) for $3 \mathrm{~min}$ at $0^{\circ} \mathrm{C}$ (power output $60 \mathrm{~W}$ at $25 \mathrm{kHz}$ ), followed by centrifuging at $100000 \mathrm{~g}$ for $\mathrm{I} \mathrm{h}$. In some experiments, nitrogen was bubbled through the cell suspension during sonication.

Enzyme assays. All assays were done on cell-free extracts at $30{ }^{\circ} \mathrm{C}$. Formaldehyde dehydrogenase (NAD/GSH-linked), EC. I.2.I.I, was assayed by the method of Johnson \& Quayle (1964), modified by using 33 mm-tris- $\mathrm{HCl}$ pH 9.3; I mm-NAD; I mm-GSH; and 0.33 mM-formaldehyde. Formate dehydrogenase, EC. I.2.I.2, was assayed by the method of Johnson \& Quayle (I964), modified by using 33 mm-tris- $\mathrm{HCl} \mathrm{pH} \mathrm{8.0;} \mathrm{I} \mathrm{mM-}$ NAD and 33 mm-sodium formate. Methanol dehydrogenase, EC. I.I.99.8, was assayed by the method of Anthony \& Zatman (1964) except that $3.3 \mu \mathrm{mol}$ of phenazine methosulphate (PMS) was used; in some experiments the enzyme was assayed by following oxygen consumption with a Rank oxygen electrode in the same assay mixture but with 2,6-dichlorophenolindophenol (DCPIP) omitted. The following enzyme activities were assayed by unmodified published methods: hydroxypyruvate reductase, EC. I.I.I.8I (Large \& Quayle, I963) measured at $\mathrm{pH}_{7.5}$ with NADH; isocitrate lyase, EC. 4. I.3. I (Dixon \& Kornberg, 1959); malyl-CoA lyase Ec. 4.1.3.24 (Salem, Hacking \& Quayle, 1973); ribulose diphosphate carboxylase, EC. 4.I.1.39 (Quayle \& Pfennig, 1975); 3-hexulose phosphate synthase by two methods (Lawrence, Kemp \& Quayle, 1970; Ferenci, Strøm \& Quayle, 1974).

Kinetic studies. Kinetic studies of methanol dehydrogenase were done spectrophotometrically in the assay system described above. Apparent Michaelis constants were determined from double reciprocal plots by the method of Lineweaver \& Burk (1934).

Analytical methods. Protein was determined by the method of Lowry et al. (195I) using bovine serum albumin as standard. Formaldehyde was estimated by the method of Nash (I953) using acetyl acetone. Formate was estimated using an NAD-linked formate dehydrogenase preparation obtained from methane-grown Pseudomonas methanica according to the method of Johnson \& Quayle (1964).

Determination of stoicheiometry of methanol- and formaldehyde-oxidation. Methanol $(\mathrm{I} \cdot 2 \mathrm{mmol})$ or formaldehyde $(2.5 \mu \mathrm{mol})$ was incubated in the reaction mixture used for assay of methanol dehydrogenase, together with $30 \mu \mathrm{g}$ of purified methanol dehydrogenase. 
After stopping the reaction by boiling for $2 \mathrm{~min}$, the mixture was acidified to $\mathrm{pH} \mathrm{I} \cdot 5$ with I $\mathrm{M}-\mathrm{HCl}$ and distilled almost to dryness. The formate and formaldehyde in the distillate were assayed as described above.

Purification of methanol dehydrogenase. Solid $\left(\mathrm{NH}_{4}\right)_{2} \mathrm{SO}_{4}$ was added to $36 \mathrm{ml}$ bacterial extract at $0{ }^{\circ} \mathrm{C}$ to achieve $55 \%$ saturation. After 30 min the precipitate was separated by centrifuging and further $\left(\mathrm{NH}_{4}\right)_{2} \mathrm{SO}_{4}$ was added to the supernatant to a final concentration of $85 \%$ saturation. After another $30 \mathrm{~min}$ the precipitate was separated by centrifuging, dissolved in $3 \mathrm{ml}$ of $50 \mathrm{~mm}$-tris- $\mathrm{HCl}$ buffer $\mathrm{pH} 8.0$ containing $10 \mathrm{mM}$-ethanol and applied to a column $(2.5 \mathrm{~cm} \times 35 \mathrm{~cm})$ of Sephadex GI50 equilibrated with the same buffer. Elution was carried out with the same buffer and $5 \mathrm{ml}$ fractions were collected. The enzyme was eluted in fractions 17 to 20 ; these were pooled and contained $50 \%$ of the activity present in the crude extract. The final specific activity $(2 \cdot 2 \mu \mathrm{mol} / \mathrm{min}$ per $\mathrm{mg}$ protein) was seven times higher than in the crude extract. The enzyme preparation was stored at $-20{ }^{\circ} \mathrm{C}$, and ethanol was removed from it by dialysing $2 \mathrm{ml}$ samples against $\mathrm{I} 1$ of $50 \mathrm{mM}-\mathrm{Tris}-\mathrm{HCl}$ buffer $\mathrm{pH} 8.0$ for $\mathrm{I} 6 \mathrm{~h}$ at $0^{\circ} \mathrm{C}$.

Purification of methanol and formaldehyde. Methanol (AR grade) was purified by using a Pye Unicam Series 104, model 64, chromatograph fitted with a $5 \mathrm{ft}$ glass column prepacked with Porapak Q (80-100 mesh) (Pye Unicam Ltd, Cambridge CBI 2PX). The oven temperature was $125^{\circ} \mathrm{C}$ and the purified methanol was collected in an ice-cooled trap fitted to a I0: I splitter assembly. Formaldehyde was prepared by heating $0.5 \mathrm{~g}$ paraformaldehyde in $5 \mathrm{ml}$ water at $100^{\circ} \mathrm{C}$ in a sealed tube for $15 \mathrm{~h}$.

Incubation of cells with $\left[{ }^{14} \mathrm{C}\right]$ methanol and $\left[{ }^{14} \mathrm{C}\right]$ bicarbonate. Bacteria growing anaerobically in the light on methanol were centrifuged and resuspended at a cell density of $4 \mathrm{mg}$ dry wt $/ \mathrm{ml}$ in a mixture of $6.6 \mathrm{~mm}-\mathrm{NaHCO}_{3}$ and $5 \mathrm{~mm}$-methanol through which was bubbled a mixture of $\mathrm{N}_{2}$ and $\mathrm{CO}_{2}(95: 5, \mathrm{v} / \mathrm{v})$ : this established a buffer system of $\mathrm{pH} 7 \cdot 0$. A $25 \mathrm{ml}$ portion of the suspension was transferred to a reaction vessel similar to the 'lollipop' vessel described by Knight (1962), and gassed with $\mathrm{N}_{2} / \mathrm{CO}_{2}$ for $10 \mathrm{~min}$ under illumination from a $500 \mathrm{~W}$ Photoflood bulb (Philips). Then a solution of $\left[{ }^{14} \mathrm{C}\right] \mathrm{methanol}(45 \mu \mathrm{mol}$; $200 \mu \mathrm{Ci})$ or sodium $\left[{ }^{14} \mathrm{C}\right]$ bicarbonate $(5 \mu \mathrm{mol} ; 200 \mu \mathrm{Ci})$ was added with a hypodermic syringe through the Suba-Seal stopper (William Freeman Ltd, Barnsley, Yorkshire) in the side of the vessel. At known time intervals, samples (approx. $2 \mathrm{ml}$ ) were removed through the stopcock into separate tubes containing $8 \mathrm{ml}$ methanol plus formic acid $(0.1 \%, v / v)$. For each isotope, blanks were prepared by heating separately $2 \mathrm{ml}$ portions of the bacterial suspension for $10 \mathrm{~min}$ at $100{ }^{\circ} \mathrm{C}$ in each of two tubes. To the cooled products in the two tubes was added $\mathrm{I} 6 \mu \mathrm{Ci}$ of the appropriate isotope and $8 \mathrm{ml}$ of methanol plus formic acid. The two blank tubes were processed with the other sample tubes as follows. Cell debris and precipitated protein were removed by centrifuging ( $5000 \mathrm{~g}$; $10 \mathrm{~min}$ ) and extracted with $0.5 \mathrm{ml}$ aqueous $20 \%(\mathrm{v} / \mathrm{v})$ methanol. The combined supernatant fluids were evaporated to dryness under reduced pressure at $40{ }^{\circ} \mathrm{C}$ and the residues taken up in $0.2 \mathrm{ml}$ aqueous $20 \%(\mathrm{v} / \mathrm{v})$ methanol for chromatography.

Chromatography and identification of labelled compounds. A portion $(0.05 \mathrm{ml})$ of each sample was chromatographed in two dimensions on Whatman no. 4 paper (18 $\frac{1}{4}$ in $\times 22$ in). The radioactive spots were located by autoradiography, assayed for radioactivity and identified by elution and co-chromatography as described by Salem, Large \& Quayle (1972). 
Table I. Substrate specificity, apparent $K_{m}$ and $V_{\max }$ values for the methanol dehydrogenase from $R h$. acidophila strain 10050

The enzyme activities were measured under the standard conditions of assay, described in Methods, with $0.03 \mathrm{mg}$ protein of the purified methanol dehydrogenase per $3 \mathrm{ml}$. $V_{\max }$ is the maximum velocity of the enzyme reaction in $\mu$ mol DCPIP reduced per min in $3 \mathrm{ml}$ of assay mixture.

Substrate
Methanol
Ethanol
Propan-I-ol
Propan-2-ol
Butan-I-ol
2-Methylpropan-I-ol
Decan-I-ol
Formaldehyde
Acetaldehyde
Propionaldehyde

$\begin{array}{cc}\text { Apparent } K_{m}(\mathrm{~mm}) & V_{\max } \\ 120 & 0.043 \\ 0.03 & 0.081 \\ 0.04 & 0.080 \\ 5.2 & 0.078 \\ 0.4 & 0.079 \\ 0.4 & 0.080 \\ 0.6 & 0.077 \\ 2.9 & 0.076 \\ 3.1 & 0.078 \\ 3.4 & 0.079\end{array}$

RESULTS

Oxidation of $C_{1}$ compounds

Methanol. Rhodopseudomonas acidophila strain 10050, grown anaerobically in the light on methanol/bicarbonate, contained a methanol dehydrogenase which could be coupled to phenazine methosulphate as electron acceptor. The enzyme was purified sevenfold as detailed in Methods. It was unstable, losing all activity after $24 \mathrm{~h}$ at $0{ }^{\circ} \mathrm{C}$, but it could be considerably stabilized by addition of $10 \mathrm{~mm}$-ethanol. The enzyme had a $\mathrm{pH}$ optimum of 9, was specific for PMS as electron acceptor and had an absolute requirement for ammonium or methylammonium ions. A broad substrate specificity in respect of aliphatic alcohols and aldehydes was observed (Table 1). The purified enzyme was not inhibited by potassium cyanide, ferric chloride, mercuric chloride, $p$-chloromercuribenzoate or EDTA (all at I mM concentration), but was $50 \%$ inhibited in the presence of 10 mm-potassium cyanide or $50 \mathrm{~mm}$-EDTA. Concentrated solutions of the methanol dehydrogenase were yellow, showing absorption maxima in $50 \mathrm{~mm}$-tris- $\mathrm{HCl}$ buffer $\mathrm{pH} 8 \cdot 0$ at 272 and $345 \mathrm{~nm}$.

The enzyme is similar in these properties to the methanol dehydrogenase first discovered in Pseudomonas sp. M27 by Anthony \& Zatman (1964), and since found in many methaneand methanol-oxidizing bacteria (Sperl, Forrest \& Gibson, 1974). There are however some differences in the detailed substrate specificity, e.g. the secondary alcohol, propan-2-ol, was dehydrogenated as was propionaldehyde. The most striking difference was the very high $K_{m}$ value for methanol. The methanol dehydrogenases from many bacteria show an apparent $K_{m}$ for methanol of $\mathrm{I} \times 10^{-5}$ to $2 \times 10^{-5} \mathrm{M}$ and higher values for all other substrates (Sperl et al., 1974). Thus not only does the methanol dehydrogenase from $R h$. acidophila show a value for the apparent $K_{m}$ with respect to methanol which is approximately $10^{4}$ times higher than that for other methanol dehydrogenases, but this value is also higher than that for any other substrate which gave a measurable rate of reaction. The possibility that an impurity in the methanol was being oxidized, rather than methanol itself, was eliminated by the finding that purification of the methanol by v.p.c. did not affect the result. Furthermore, in the presence of excess methanol, $0.3 \mathrm{I} \mu \mathrm{mol}$ of formaldehyde and $0.15 \mu \mathrm{mol}$ of formate were produced after consumption of $0.355 \mu \mathrm{mol}$ of $\mathrm{O}_{2}$. With excess formaldehyde as substrate, $0.65 \mu \mathrm{mol}$ of formaldehyde was oxidized to 0.57 $\mu \mathrm{mol}$ of formate after consumption of $0.30 \mu \mathrm{mol}$ of $\mathrm{O}_{2}$. These results show that the enzyme oxidizes methanol to formaldehyde and formaldehyde to formate. 
Table 2. Activities of methanol, formaldehyde and formate dehydrogenases of $R h$. acidophila grown on different carbon sources

The organism was grown on different carbon sources anaerobically in the light.

\begin{tabular}{lccc} 
& \multicolumn{3}{c}{ Specific activities $(\mu \mathrm{mol} / \mathrm{min}$ per mg protein) } \\
\cline { 2 - 4 } Carbon source & Methanol dehydrogenase & Formaldehyde dehydrogenase & Formate dehydrogenase \\
Methanol & 0.33 & 0.74 & 0.03 \\
Ethanol & 0.35 & 0.03 & 0 \\
Propan-I-ol & 0.29 & 0.02 & 0 \\
Butan-I-ol & 0.25 & 0.02 & 0 \\
Na-Formate & 0.05 & 0.02 & 0.03 \\
Na-Succinate & 0.08 & 0.03 & 0
\end{tabular}

The apparent $K_{m}$ value for methanol, determined in a crude cell-free extract, was lowered to $2 \mathrm{mM}$ if the extract was prepared anaerobically and assayed anaerobically. The rate of reduction of DCPIP in the blank cuvette that lacked methanol was much higher under anaerobic than aerobic conditions. In order to observe the lowering of the apparent $K_{m}$ value both the preparation of extract and the assay had to be done under anaerobic conditions; it was not sufficient to do only one operation anaerobically.

Formaldehyde. Extracts of $R h$. acidophila strain 10050, grown anaerobically in the light on methanol/bicarbonate, contained an NAD-linked formaldehyde dehydrogenase which required GSH for activity. No reaction was observed if NADP was substituted for NAD or cysteine for GSH. Formaldehyde and methyl glyoxal served as substrates, but not acetaldehyde, propionaldehyde, butyraldehyde, glyoxal, methanol or formate. Under the standard conditions of assay given in Methods, the apparent $K_{m}$ values for formaldehyde, NAD and GSH were $0.07,0.08$ and $0.05 \mathrm{~mm}$ respectively. In tris- $\mathrm{HCl}$ buffer, the enzyme showed maximum activity at $\mathrm{pH} 9 \cdot 3$. Similar enzymes have been found in other organisms grown on one-carbon substrates (Quayle, 1972; Ogata, Tani \& Kato, 1975; Sahm \& Wagner, I973).

Formate. An NAD-linked formate dehydrogenase was found in extracts of methanol- or formate-grown $R h$. acidophila. NAD could not be replaced by NADP and the enzyme showed no detectable activity with methanol, formaldehyde, acetate or pyruvate. The enzyme was labile and lost all activity on freezing or on storage at $4{ }^{\circ} \mathrm{C}$ for $24 \mathrm{~h}$. The $\mathrm{pH}$ optimum of the dehydrogenase was at $\mathrm{pH}$ 8. Unlike the NAD-linked formate dehydrogenase found in Rhodopseudomonas palustris by Yoch \& Lindstrom (1969), the enzyme found in $R h$. acidophila was not stimulated by FMN or FAD.

Enzyme activities in Rh. acidophila grown on different substrates. The activities of the methanol, formaldehyde and formate dehydrogenases in $R h$. acidophila grown anaerobically in the light on various substrates are shown in Table 2. Little or no activity was observed in the succinate-grown organism. All three enzymes were present in the organism grown on methanol, whereas only the methanol dehydrogenase was present in appreciable amounts during growth on higher alcohols. Neither methanol dehydrogenase nor formaldehyde dehydrogenase was synthesized during growth on formate.

These results show that control of synthesis of the three enzymes is not co-ordinate. The raised specific activity of the methanol dehydrogenase during growth on ethanol, propan-I-ol and butan-I-ol indicates that the enzyme is involved in metabolism of these substrates; this conclusion is consistent with the broad substrate specificity of the enzyme (Table I). 
Table 3. Incorporation of $\left[{ }^{14} \mathrm{C}\right]$ methanol by $R h$. acidophila strain 10050

$\left[{ }^{14} \mathrm{C}\right.$ ]Methanol $(45 \mu \mathrm{mol} ; 200 \mu \mathrm{Ci})$ was added at zero time to $25 \mathrm{ml}$ of a suspension of bacteria ( $4 \mathrm{mg}$ dry wt/ml) in $6.6 \mathrm{~mm}-\mathrm{NaHCO}_{3}$ containing $5 \mathrm{~mm}$-methanol. The suspension was gassed with $\mathrm{N}_{2}-\mathrm{CO}_{2}(95: 5, \mathrm{v} / \mathrm{v})$ under illumination. Samples (approx. $2 \mathrm{ml}$ ) were removed at intervals into $8 \mathrm{ml}$ of methanol containing formic acid $(0.1 \%, \mathrm{v} / \mathrm{v})$, centrifuged and the pellets extracted with $0.5 \mathrm{ml}$ of aqueous $20 \%(\mathrm{v} / \mathrm{v})$ methanol. The combined supernatant fluids were analysed by chromatography and autoradiography as detailed in Methods.

\begin{tabular}{cccccc} 
& \multicolumn{4}{c}{ Radioactivity (c.p.m)* } \\
Time (s) & Malate & Aspartate & Citrate/isocitrate & Glutamate & Total \\
5 & 16 & $<2$ & 12 & 19 & 47 \\
10 & 58 & 56 & 20 & 71 & 205 \\
15 & 54 & 59 & 5 & 108 & 226 \\
21 & 40 & 55 & $<2$ & 109 & 204 \\
26 & 62 & 75 & $<2$ & 170 & 307
\end{tabular}

* Corrected for a background radioactivity of 60 c.p.m.

Table 4. Incorporation of $\left[{ }^{14} \mathrm{C}\right]$ bicarbonate by $R$ h. acidophila strain 10050

Experimental details are identical to those in Table 3 except that sodium $\left[{ }^{14} \mathrm{C}\right]$ bicarbonate $(5 \mu \mathrm{mol}$; $200 \mu \mathrm{Ci})$ was added at zero time in place of $\left[{ }^{14} \mathrm{C}\right] \mathrm{methanol}$.

\begin{tabular}{rrrrrrrrr}
\multicolumn{8}{c}{ Radioactivity (c.p.m.)* } \\
Time (s) & $\begin{array}{c}\text { Phosphorylated } \\
\text { compounds }\end{array}$ & Malate & Aspartate & $\begin{array}{c}\text { Citrate/ } \\
\text { isocitrate }\end{array}$ & Serine & Glutamate & Glycine & Total \\
4 & 25 & 19 & $<2$ & $<2$ & $<2$ & $<2$ & $<2$ & 44 \\
10 & 187 & 34 & 31 & 2 & $<2$ & $<2$ & $<2$ & 254 \\
16 & 485 & 82 & 134 & 35 & $<2$ & $<2$ & $<2$ & 736 \\
23 & 529 & 130 & 132 & 15 & $<2$ & $<2$ & $<2$ & 806 \\
29 & 806 & 133 & 279 & 39 & 45 & 44 & 46 & 1392
\end{tabular}

* Corrected for a background radioactivity of 60 c.p.m.

\section{Assimilation of $C_{1}$ compounds}

Incorporation of $\left[{ }^{14} \mathrm{C}\right]$ methanol and $\left[{ }^{14} \mathrm{C}\right]$ bicarbonate by the intact organism. The uptake of $\left[{ }^{14} \mathrm{C}\right]$ methanol into cell constituents of $R h$. acidophila strain 10050 , during growth of the organism anaerobically in the light on methanol/bicarbonate, was followed over $2 \mathrm{~min}$ incubation as detailed in Methods. The results for the first $26 \mathrm{~s}$ of incubation are given in Table 3. The total amount of isotope fixed increased rapidly for the first $10 \mathrm{~s}$ but the rate of increase was not maintained thereafter. Malate, glutamate, citrate/isocitrate and aspartate were labelled and their percentage plots showed negative slopes initially (Fig. I), although the amount of isotope fixed after $5 \mathrm{~s}$ was so small that the first point on each curve cannot be given much significance. No incorporation of isotope into phosphorylated compounds or serine was detected within the first $30 \mathrm{~s}$. Hence there is no evidence for operation of the ribulose monophosphate pathway of formaldehyde fixation (Strøm, Ferenci \& Quayle, 1974) or the serine pathway in either of its variants (Quayle, I972; Bellion \& Hersh, 1972). The results might be explained by oxidation of the $\left[{ }^{14} \mathrm{C}\right]$ methanol to ${ }^{14} \mathrm{CO}_{2}$ within the cell, followed by fixing of the ${ }^{14} \mathrm{CO}_{2}$ into oxaloacetate. This could then give rise to malate, aspartate, citrate/isocitrate and glutamate.

The pattern of uptake of $\left[{ }^{14} \mathrm{C}\right]$ bicarbonate was followed in a similar experiment using $25 \mathrm{ml}$ of the same stock suspension of bacteria as used in the previous experiment. The 


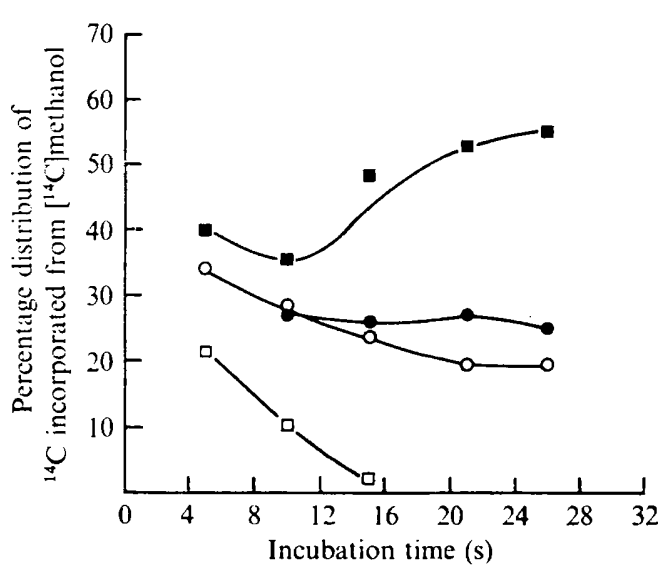

Fig. I

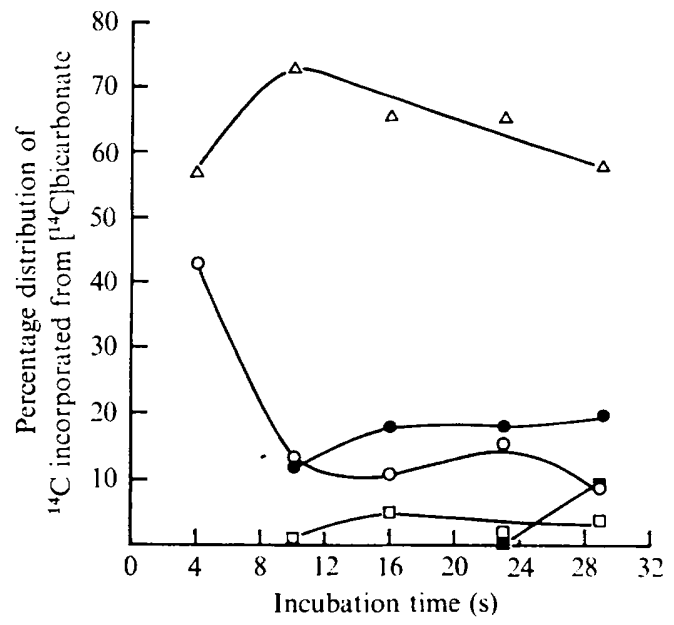

Fig. 2

Fig. I. Variation with time of the percentage distribution of ${ }^{14} \mathrm{C}$ incorporated from $\left[{ }^{14} \mathrm{C}\right] \mathrm{methanol}$ into the constituents of the methanol-soluble fraction of $R h$. acidophila growing on methanol/ bicarbonate anaerobically in the light. $O$, Malate;, aspartate; $\square$, citrate; $\mathbf{n}$, glutamate.

Fig. 2. Variation with time of the percentage distribution of ${ }^{14} \mathrm{C}$ incorporated from $\left[{ }^{14} \mathrm{C}\right]$ bicarbonate into the constituents of the methanol-soluble fraction of $R h$. acidophila growing on methanol/ bicarbonate anaerobically in the light. $O$, Malate; $O$, aspartate; $\square$, citrate; $\square$, serine + glycine + glutamate; $\triangle$, phosphorylated compounds.

results for the first $29 \mathrm{~s}$ of incubation are given in Table 4. The total amount of isotope fixed increased throughout the incubation period, and most of it was contained in phosphorylated compounds. Analysis of these compounds after enzymic dephosphorylation showed that they were mainly phosphates of glyceric acid, glucose and fructose. The percentage plots of incorporation into the different metabolites are shown in Fig. 2; as in Fig. I, no great significance is placed on the values of the percentages of isotope in malate and phosphorylated compounds after $4 \mathrm{~s}$ incubation because the total amount fixed at this time was so small. The results are typical for an autotrophic organism fixing carbon dioxide through the ribulose diphosphate cycle and also, to a lesser extent, through a $\mathrm{C}_{3}+\mathrm{CO}_{2}$ fixation reaction into oxaloacetate or malate. Bearing in mind the lack of evidence for incorporation of isotope from $\left[{ }^{14} \mathrm{C}\right]$ methanol into cell constituents via a reduced $\mathrm{C}_{1}$ fixation cycle, it may be concluded that the organism oxidizes methanol to carbon dioxide and, in effect, grows autotrophically upon it. At first sight it might appear that, if this were so, the pattern of incorporation of $\left[{ }^{14} \mathrm{C}\right]$ methanol should be identical with that for $\left[{ }^{14} \mathrm{C}\right]$ bicarbonate. The conditions for incorporation of the two isotopes were, however, unavoidably different in the two experiments. In the first case $\left[{ }^{14} \mathrm{C}\right]$ methanol (from $200 \mu \mathrm{Ci}$ of added isotope) was oxidized at an unknown rate to ${ }^{14} \mathrm{CO}_{2}$ within the bacterial cells which were suspended in a medium containing $214 \mu \mathrm{mol}$ of 'unlabelled $\mathrm{CO}_{2} / \mathrm{HCO}_{3}{ }^{-} / \mathrm{CO}_{3}^{2-}$; in the second case, isotope from $200 \mu \mathrm{Ci}$ of labelled $\mathrm{CO}_{2} / \mathrm{HCO}_{3}{ }^{-} / \mathrm{CO}_{3}^{2-}$ (total of $219 \mu \mathrm{mol}$ ) entered the cells from the medium. These two situations are very different and it is not possible to predict how the ${ }^{14} \mathrm{CO}_{2}$ would be handled in these two cases by the different carbon dioxide fixation enzymes in the organism. It should be emphasized that the isotopic experiments were designed primarily to detect fixation of reduced $C_{1}$ units in one case, and carbon dioxide in the other, and to identify any assimilatory sequences found to operate. 
Table 5. Specific activities of biosynthetic enzymes in extracts of $R h$. acidophila strain 10050

The organism was grown anaerobically in the light in batch culture, except where otherwise stated.

\begin{tabular}{lcc} 
& Specific activity $(\mu \mathrm{mol} / \mathrm{min}$ per mg protein $)$ \\
\cline { 2 - 3 } $\begin{array}{l}\text { Growth substrate } \\
\text { Rethanol diphosphate } \\
\text { carboxylase }\end{array}$ & $\begin{array}{c}\text { Hydroxypyruvate } \\
\text { reductase }\end{array}$ \\
Ethanol & $0.04^{*}$ & 0.026 \\
Succinate & Not tested & 0.029 \\
& 0.008 & 0.030 \\
& * Turbidostat culture.
\end{tabular}

Activity of biosynthetic enzymes. No detectable activity of the following enzymes was found in extracts of the organism grown anaerobically in the light on methanol, ethanol or succinate: hexulose phosphate synthase, isocitrate lyase and malyl-CoA lyase. A constant amount of hydroxypyruvate reductase activity was observed in the organism grown on the three different substrates (Table 5). These results indicate that neither the ribulose monophosphate pathway of formaldehyde fixation nor either known variant of the serine pathway operates during phototrophic growth of the organism on methanol. Extracts of the organism grown on methanol in the turbidostat showed ribulose diphosphate carboxylase activity at a specific activity of $0.04 \mu \mathrm{mol}$ ribulose diphosphate carboxylated $/ \mathrm{min}$ per $\mathrm{mg}$ protein; the specific activity was lowered fivefold in the organism grown on succinate (Table 5).

If it is assumed that the organism contains $50 \%$ carbon and $50 \%$ protein, then a specific activity of $0.036 \mu \mathrm{mol}$ ribulose diphosphate carboxylated/min per $\mathrm{mg}$ protein would suffice to sustain autotrophic growth at a mean generation time equal to that obtaining in the turbidostat viz. $29 \mathrm{~h}$. This calculated specific activity may be compared with the value of 0.04 which was actually found.

\section{DISCUSSION}

The studies reported in this paper demonstrate that when $R h$. acidophila strain 10050 is growing anaerobically in the light on methanol, it possesses enzymes which can oxidize methanol to carbon dioxide via formaldehyde and formate as intermediates. The enzyme of dual specificity which can couple the oxidation of methanol or formaldehyde to the reduction of PMS is clearly similar in many respects to the ubiquitous methanol dehydrogenase discovered by Anthony \& Zatman (1964). This classical methanol dehydrogenase has hitherto been found only in aerobic bacteria and the properties of the enzyme obtained from various organisms are very uniform (Sperl et al., 1974). As far as we are aware, the methanol dehydrogenase from $R h$. acidophila is the first example of an enzyme of this type involved in anaerobic metabolism. This may be relevant to the remarkable property possessed by this enzyme of having a $K_{m}$ value for methanol which is apparently increased by a factor of 10 when the enzyme is exposed to air. This suggests that the conformation of the enzyme is altered in the presence of oxygen, resulting in a decreased affinity for methanol. It is not known whether a corresponding change in affinity occurs in respect of the other alcohols and aldehydes which can serve as substrates, and further investigation of this effect is needed, particularly with enzyme which has been purified throughout in the complete absence of oxygen. The fact that exposure to oxygen apparently results in the enzyme having a very low affinity for methanol $\left(K_{m}\right.$, $\left.120 \mathrm{mM}\right)$ may explain a puzzling 
feature of the growth physiology of $R h$. acidophila; we have been unable to grow it aerobically on methanol despite the fact that the organism grows well either aerobically or anaerobically in the light on a wide variety of other organic substrates (Pfennig, 1969), including ethanol which is dehydrogenated by the same enzyme. There might of course be other explanations in view of the autotrophic mode of phototrophic growth on methanol adopted by the organism, e.g. the effect of oxygen on the synthesis of enzymes of the ribulose diphosphate cycle. Such alternatives have not been eliminated in this study.

The results of the isotopic experiments indicate that carbon is assimilated as carbon dioxide via the ribulose diphosphate cycle. There is no evidence for operation of any known reduced $\mathrm{C}_{1}$-fixation sequence. The more pronounced labelling of glutamate from $\left[{ }^{14} \mathrm{C}\right]-$ methanol than from $\left[{ }^{14} \mathrm{C}\right]$ bicarbonate is unexpected. A somewhat similar observation was made by Yoch \& Lindstrom ( 1967 ) in respect of $\left[{ }^{14} \mathrm{C}\right]$ formate incorporation by $R$ h. palustris grown anaerobically in the light. These authors speculated that early appearance of labelled glutamate may have been due to formation of $\alpha$-oxoglutarate by reductive carboxylation of succinyl-CoA, the carbon dioxide arising from dehydrogenation of formate. A similar speculation may be made in respect of $R h$. acidophila and calls for further experimentation.

The conclusion from the isotopic experiments that growth of $R h$. acidophila on methanol is autotrophic is borne out by the enzyme profile of the organism. Ribulose diphosphate carboxylase was present at a specific activity sufficient to account for the actual growth rate of the organism measured in the turbidostat. Its specific activity dropped fivefold during growth on succinate. By contrast, key enzymes of the ribulose monophosphate cycle of formaldehyde fixation and of the serine pathway, e.g. hexulose phosphate synthase, malylCoA lyase and isocitrate lyase, were absent. Although a key enzyme of the serine pathway, hydroxypyruvate reductase, was present at a low activity, the fact that its specific activity was higher in the ethanol- or succinate-grown organism than in the methanol-grown organism casts doubt on its specific involvement in $\mathrm{C}_{1}$-assimilation. In organisms where this enzyme is involved in $\mathbf{C}_{\mathbf{1}}$-assimilation it is usually present at high specific activity (approx. I $\mu \mathrm{mol} / \mathrm{min}$ per $\mathrm{mg}$ protein).

Growth of $R h$. acidophila on methanol is the second case of autotrophic growth on this substrate to be reported; the first case is that of Micrococcus denitrificans (Cox \& Quayle, 1975). It is probably significant that both of these organisms are facultative autotrophs and hence acquisition of the ability merely to oxidize $C_{1}$ compounds would, without the elaboration of further biosynthetic enzymes, confer upon the organisms the capability of growth on such compounds. The gain in nutritional versatility, at such little cost in fashioning of extra enzymes, probably outweighs the disadvantage of using a more energetically costly pathway than a formaldehyde fixation sequence such as the ribulose monophosphate cycle or serine pathway (Strøm et al., 1974). It may well be that autotrophic growth on highly-reduced $C_{1}$ substrates is a luxury to be enjoyed only by facultative autotrophs.

We thank Mr A. A. Hancock for his skilled technical assistance, and the Science Research Council for financial support under Grant no. B/RG/27II8 and a Visiting Fellowship (to H.S.).

\section{REFERENCES}

ANTHONY, C. \& ZATMAN, L. J. (1964). The microbial oxidation of methanol. The methanol oxidizing enzyme of Pseudomonas sp. M27. Biochemical Journal 96, 808-8I 2.

Bellion, E. \& Hersh, L. B. (1972). Methylamine metabolism in a Pseudomonas species. Archives of Biochemistry and Biophysics 153, 368-374.

CoX, R. B. \& QUAYLE, J. R. (1975). The autotrophic growth of Micrococcus denitrificans on methanol. Biochemical Journal 150, 569-571. 
Dixon, G. H. \& Kornberg, H. L. (1959). Assay methods for key enzymes of the glyoxylate cycle. Biochemical Journal 72, ${ }_{3} P$.

Ferenci, T., StRøm, T. \& QuAYLE, J. R. (1974). Purification and properties of 3-hexulose phosphate synthase and phospho-3-hexuloisomerase from Methylococcus capsulatus. Biochemical Journal 144, 477-486.

Johnson, P. A. \& QuAYLE, J. R. (1964). Microbial growth on $\mathrm{C}_{1}$ compounds. 6. Oxidation of methanol, formaldehyde and formate by methanol-grown Pseudomonas AmI. Biochemical Journal 93, 281-290.

KNiGHT, M. (1962). The photometabolism of propionate by Rhodospirillum rubrum. Biochemical Journal $84,170-185$.

LaRge, P. J. \& Quayle, J. R. (1963). Microbial growth on $C_{1}$ compounds. 5. Enzyme activities in extracts of Pseudomonas AMI. Biochemical Journal 87, 386-396.

Lawrence, A. J., Kemp, M. B. \& QuayLe, J. R. (1970). Synthesis of cell constituents by methane-grown Methylococcus capsulatus and Methanomonas methanooxidans. Biochemical Journal 115, 63I-639.

LINEWEAVER, H. \& BURK, D. (1934). The determination of enzyme dissociation constants. Journal of the American Chemical Society 56, 658-666.

Lowry, O. H., Rosebrough, N. J., Farr, A. L. \& Randall, R. J. (1951). Protein measurement with the Folin phenol reagent. Journal of Biological Chemistry 193, 265-275.

NASH, T. (1953). The colorimetric estimation of formaldehyde by means of the Hantzsch reaction. Biochemical Journal 55, 416-42I.

Ogata, K., Tani, Y. \& Kato, N. (1975). Oxidation of methanol by yeasts. In Microbial Growth on $C_{1}$ Compounds, pp. 99-1 19. Tokyo: Society of Fermentation Technology, Japan.

PFenNig, N. (1969). Rhodopseudomonas acidophila, sp.n., a new species of the budding purple nonsulfur bacteria. Journal of Bacteriology 99, 597-602.

QuAYLE, J. R. (1972). The metabolism of one-carbon compounds by micro-organisms. In Advances in Microbial Physiology, vol. 7, pp. I19-203. Edited by A. H. Rose and D. W. Tempest. London and New York: Academic.

Quayle, J. R. \& Kfech, D. B. (1959). Carbon assimilation by Pseudomonas oxalaticus (oxi). 2. Formate and carbon dioxide utilization during growth on formate. Biochemical Journal 72, 63I-637.

Quayle, J. R. \& Pfennig, N. (1975). Utilization of methanol by Rhodospirillaceae. Archives of Microbiology 102, 193-198.

SAHM, H. \& WAGNER, F. (1973). Mikrobielle Verwertung von Methanol. Eigenschaften der Formaldehydedehydrogenase und der Formiatdehydrogenase aus Candida boidinii. Archiv für Mikrobiologie 9o, 263-268

Salem, A. R., Hacking, A. J. \& Quayle, J. R. (1973). Cleavage of malyl-coenzyme A into acetyl-coenzyme $\mathrm{A}$ and glyoxylate by Pseudomonas AMI and other $\mathrm{C}_{1}$-unit-utilizing bacteria. Biochemical Journal 136, $89-96$.

Salem, A. R., Large, P. J. \& Quayle, J. R. (1972). Glycine formation during growth of Pseudomonas AMI on methanol and succinate. Biochemical Journal 128, I 203-I 2 I I.

SLATER, J. H. \& MORRIS, I. (1973). Pathway of carbon dioxide assimilation in Rhodospirillum rubrum grown in turbidostat continuous flow culture. Archiv für Mikrobiologie 92, 235-244.

SperL, G. T., Forrest, H. S. \& Gibson, D. T. (1974). Substrate specificity of the purified primary alcohol dehydrogenases from methanol-oxidizing bacteria. Journal of Bacteriology 118, 541-550.

StOKES, J. E. \& HoARE, D. S. (1969). Reductive pentose cycle and formate assimilation in Rhodopseudomonas palustris. Journal of Bacteriology 100, 890-894.

Strgm, T., Ferenci, T. \& Quayle, J. R. (1974). The carbon assimilation pathways of Methylococcus capsulatus, Pseudomonas methanica and Methylosinus trichosporium (Ов3в) during growth on methane. Biochemical Journal 144, 465-476.

Yoch, D. C. \& Linostrom, E. S. (1967). Photosynthetic conversion of formate and $\mathrm{CO}_{2}$ to glutamate by Rhodopseudomonas palustris. Biochemical and Biophysical Research Communications 28, 65-69.

Yосн, D. C. \& LiNDSTrom, E. S. (1969). Nicotinamide adenine dinucleotide-dependent formate dehydrogenase from Rhodopseudomonas palustris. Archiv fïr Mikrobiologie, 67, 182-188. 